\title{
Efektivitas Buku Saku PHBS di Sekolah dalam Meningkatkan Perilaku Hidup Bersih dan Sehat
}

\author{
Muthmainah Farida Hanif ${ }^{1}$, Mury Ririanty ${ }^{1}$, Iken Nafikadhini ${ }^{1}$ \\ Fakultas Kesehatan Masyarakat, Universitas Jember, Indonesia ${ }^{1}$ \\ e-mail: muthmainahfaridahanif@gmail.com
}

\begin{abstract}
School children become one of the most vulnerable groups to health problems due to environmental factors and poor lifestyles, so they need for a strong support from the environment in the formation of Clean and Healthy Behavior (PHBS) among school children. The methods and props used in health promotion need to be given careful attention, so that the material or ingredients can easily accepted, assimilated and absorbed by the target. The PHBS pocketbook in school is one of publication media of health promotion which had been through expert test and late published, but the PHBS pocketbook in school has not done effectiveness test to the target audiences. This study aimed to analyze the effectiveness of PHBS pocketbook in schools in improving knowledge, attitudes and intentions of PHBS in primary school children. This research was a real experimental study used Pretest Posttest design with control group conducted in SDN Krembangan Selatan 10, SDN Perak Barat 6 and SDN Kemayoran 1. The results of this study indicate that the value of knowledge, attitude and intention are better after the intervention had given to the experimental group $A$ through the PHBS pocketbook in school and counseling, as well as experiment group B through the PHBS pocketbook in school, while the control group has the same value because no intervention was done. PHBS pocketbook media in those school proved able to increase knowledge, attitude and intention in clean and healthy life behavior in elementary school children.
\end{abstract}

Keywords : behavior, effectiveness, PHBS, pocketbook, school

\section{Pendahuluan}

PHBS di Sekolah adalah pondasi dari perilaku kesehatan yang bisa diraih oleh siswa. Oleh karena itu, harus dipromosikan program kesehatan sekolah terkait kebersihan diri dan sanitasi lingkungan untuk mencegah penyakit di lingkungan sekolah. Proses belajar mengajar harus mengedepankan pendidikan kesehatan PHBS agar siswa mampu mandiri dalam mempraktikkan kesehatan dasar melalui kegiatan intra dan ekstrakurikuler yang sesuai (Susanto, Tantut, Lantin, Emi, Syahroni, 2016).

Berdasarkan data dari Dinas Kesehatan Surabaya (2016), rata-rata prosentase PHBS di rumah tangga kota Surabaya sebesar $75,07 \%$, angka ini telah mencapai target PHBS di rumah tangga provinsi Jawa Timur sebesar 53\%, namun, masih ada wilayah kerja puskesmas yang paling rendah yaitu puskesmas Krembangan Selatan dengan prosentase $48 \%$ (Dinas Kesehatan Kota Surabaya, 2016). Terdapat 3 kelurahan yang dinaungi oleh Puskesmas Krembangan Selatan yaitu kelurahan Krembangan Selatan, Perak Barat dan Kemayoran. Berdasarkan data dari puskesmas Krembangan Selatan (2016), siswa SDN Krembangan Selatan 10 di kelurahan Krembangan Selatan, siswa SDN Perak Barat 6 di kelurahan Perak Barat dan siswa SDN Kemayoran 1 di kelurahan. Kemayoran merupakan siswa yang paling banyak berkunjung kepuskesmas untuk melakukan pengobatan sebanyak 27 kali, 25 kali dan 24 kali di tahun 2017 (Puskesmas Krembangan Selatan, 2017). Pengobatan yang dilakukan diantaranya pengobatan penyakit diare, flu, batuk, demam, gatalgatal, dan demam berdarah. Penyakitpenyakit tersebut berkaitan erat dengan PHBS.

Anak sekolah menjadi salah satu kelompok paling rentan terhadap terjadinya masalah kesehatan karena faktor lingkungan dan pola hidup yang kurang baik. Data nasional mencatat bahwa $16 \%$ angka kejadian keracunan nasional terjadi di lingkungan sekolah dan diare menempati urutan pertama dari angka kejadian infeksi saluran pencernaan pada tahun 2006 sampai 2010. Sedangkan 5.000 anak meninggal dunia setiap hari akibat serangan diare. Data tersebut menunjukkan perlunya suatu dukungan yang kuat dari lingkungan dalam 
pembentukan PHBS dikalangan anak sekolah (Kholid, 2014).

Perubahan perilaku seseorang dapat dipengaruhi oleh pengetahuan, sikap dan intensi. Upaya penyampaian informasi pemilihan media sangat penting dan perlu diperhatikan karena pemilihan dan penyampaian yang benar akan memberikan hasil yang maksimal dalam peningkatan pengetahuan, sikap dan intensi (Luthviatin, N., Zulkarnain, E., Istiaji, E., Rokhmah., D., 2012). Buku saku merupakan salah satu media cetak promosi kesehatan yang memiliki kelebihan diantaranya tahan lama, mencakup banyak orang, biaya tidak tinggi, dapat dibawa kemana-mana, mempermudah pemahaman dan meningkatkan gairah belajar (Kholid, 2014).

Penerbitan buku ini pada tahun 2015 oleh UPT. Penerbitan Universitas Jember dengan nomor ISBN 9786029030754. Buku saku ini telah melalui uji coba ahli media, ahli promosi kesehatan dan ahli perilaku kesehatan, namun buku saku PHBS di sekolah ini belum dilakukan uji efektvitas kepada khalayak sasaran.

Peneliti menggunakan teori difusi inovasi oleh Rogers dalam Glanz et al., difusi merupakan keseluruhan penyebaran sebuah inovasi, proses dimana sebuah inovasi dikomunikasikan melalui saluran tertentu dari waktu ke waktu di antara anggota sistem, sedangkan inovasi merupakan ide, praktek, atau objek yang dianggap baru oleh individu atau unit adaptasi lainnya (Glanz, Karen., Barbara K. Rimer., K. Viswanath, 2008). Tujuan penelitian ini untuk menganalisis efektivitas buku saku PHBS di sekolahdalam meningkatkan pengetahuan, sikap dan intensi PHBS pada anak sekolah dasar.

\section{Metode}

Penelitian ini jenis penelitian kuantitatif menggunakan eksperimen sungguhan dengan rancangan Pretest Posttest dengan kelompok kontrol yang melibatkan lebih dari satu variabel bebas. Penelitian ini dilaksanakan pada bulan MaretApril 2018 di SDN Krembangan Selatan 10 sebagai kelompok eksperimen A yang mendapatkan intervensi buku saku PHBS di sekolah dan penyuluhan, SDN Perak Barat 6 sebagai kelompok eksperimen B mendapatkan intervensi buku saku PHBS di sekolah saja, dan SDN Kemayoran 1 Surabaya sebagai kelompok kontrol yang tidak mendapatkan intervensi.

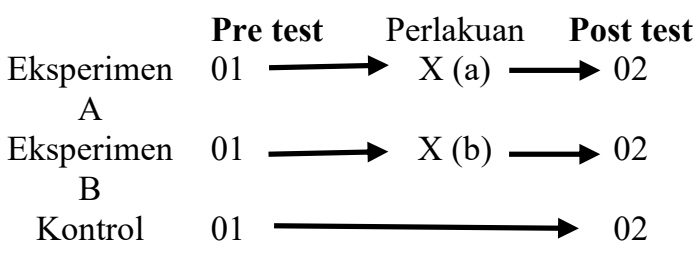

Gambar 1 Rancangan penelitian

\subsection{Metode Pengumpulan Data}

Metode pengumpulan data yang digunakan yaitu wawancaara dengan pendekatan pre test dan post test. Penentuan besar sampel pada penelitian ini dengan menggunakan probability sampling yaitu proportionate stratified random sampling, didapatkan hasil sampel sebanyak 86 responden dari total keseluruhan 600 orang. Sampel yang didapatkan dibagi ke 3 sekolah menggunakan rumus alokasi proportional menjadi kelompok eksperimen A 28 responden, kelompok eksperimen B 29 responden dan kelompok kontrol 29 responden.

\subsection{Metode Analisis Data}

Analisis data yang digunakan menggunakan analisis univariat dan analisis bivariat. Analisis univariat untuk mendeskripsikan karakteristik setiap variabel Penelitian meliputi jenis kelamin, pendidikan, pengetahuan, sikap dan intensi (Notoatmodjo, 2012). Analisis bivariat yang digunakan peneliti yaitu Uji Willcoxon Rank Test yang bertujuan untuk mengetahui perbedaan dari pengetahuan, sikap, dan intensi mengenai PHBS sebelum dan sesudah diberikan intervensi. Selain itu, Uji Kruskal Wallis digunakan untuk menentukan adakah perbedaan signifikan secara statistik antara dua atau lebih kelompok variabel independen pada variabel dependen dengan tujuan menentukan kelompok yang paling tinggi hasilnya dan dianggap paling efektif. 
ISSN 2354-5852

E-ISSN 2579-5783

\section{Hasil dan Pembahasan}

Karakteristik responden meliputi jenis kelamin, pendidikan, pengetahuan, sikap dan intensi diuraikan sebagai berikut. dapat dilihat pada tabel 1 .

Tabel 1. Karakteristik responden

\begin{tabular}{|c|c|c|c|c|c|c|c|}
\hline \multirow[t]{2}{*}{$\begin{array}{l}\text { Karakteristi } \\
\text { k Responden }\end{array}$} & \multirow[t]{2}{*}{$\mathbf{n}$} & \multicolumn{2}{|c|}{$\begin{array}{c}\text { Eksperimen } \\
\text { A }\end{array}$} & \multicolumn{2}{|c|}{$\begin{array}{c}\text { Eksperimen } \\
\text { B }\end{array}$} & \multicolumn{2}{|c|}{ Kontrol } \\
\hline & & $\mathbf{n}$ & $\%$ & $\mathbf{n}$ & $\%$ & $\mathbf{n}$ & $\%$ \\
\hline \multicolumn{8}{|l|}{ Jenis Kelamin } \\
\hline Laki-laki & 38 & 13 & 46,4 & 12 & 41,4 & 13 & $\begin{array}{l}44 \\
, 9\end{array}$ \\
\hline perempuan & 48 & 15 & 53,6 & 17 & 59,6 & 16 & $\begin{array}{l}55 \\
, 1\end{array}$ \\
\hline Total & 86 & 28 & 100 & 29 & 100 & 29 & $\begin{array}{c}10 \\
0\end{array}$ \\
\hline \multicolumn{8}{|c|}{ Tingkat Pendidikan } \\
\hline Kelas 4 & 28 & 9 & 32 & 8 & 29 & 11 & 39 \\
\hline Kelas 5 & 29 & 10 & 36 & 11 & 39 & 8 & 29 \\
\hline Kelas 6 & 27 & 9 & 32 & 9 & 32 & 9 & 32 \\
\hline Total & 86 & 28 & 100 & 29 & 100 & 29 & $\begin{array}{c}10 \\
0\end{array}$ \\
\hline
\end{tabular}

Berdasarkan tabel 1 Sebaran responden berdasarkan jenis kelamin terbanyak pada masing-masing kelompok yaitu berjenis kelamin perempuan dengan total 48 orang. Berdasarkan tingkat pendidikan kelompok eksperimen A kelas 5 merupakanresponden yang paling banyak yaitu 29 orang (36\%). Distribusi yang paling banyak pada kelompok eksperimen B yaitukelas 5 (39\%). Sedangkan, kelompok control memiliki responden paling banyak dari kelas 4 sebanyak 11 orang $(39 \%)$.

Perbedaan pengetahuan tentang PHBS di Sekolah pada kelompok eksperimen A, eksperimen B, dan kontrol dapat dilihat tabel 2.

Tabel 2. Nilai Pengetahuan pada Kelompok Eksperimen A, Eksperimen B, dan Kontrol

\begin{tabular}{lllllll}
\hline Pengetahuan & \multicolumn{2}{c}{$\begin{array}{c}\text { Eksperimen } \\
\text { A }\end{array}$} & \multicolumn{3}{c}{$\begin{array}{c}\text { Eksperimen } \\
\text { B }\end{array}$} & Kontrol \\
& \multicolumn{4}{c}{ Sebelum } \\
\hline \multirow{3}{*}{ Kurang } & $\mathrm{n}$ & $\%$ & $\mathrm{n}$ & $\%$ & $\mathrm{n}$ & $\%$ \\
Sedang & 14 & 50 & 10 & 35 & 13 & 45 \\
Baik & 11 & 40 & 14 & 48 & 14 & 48 \\
& 10 & 21 & 5 & 17 & 2 & 7
\end{tabular}

\begin{tabular}{lllllll}
\hline \multicolumn{7}{c}{ Sesudah } \\
& 2 & 7 & 3 & 10 & 12 & 41 \\
\hline Kurang & 5 & 18 & 15 & 52 & 13 & 49 \\
Sedang & 21 & 75 & 11 & 38 & 3 & 10 \\
Baik & & & & & & \\
& 0,000 & 0,001 & & 0,705 \\
\hline P value & & & & \\
\hline
\end{tabular}

Nilai pre test pada kelompok kontrol yaitu 5 responden atau 17\% memiliki sikap baik, setelah diberikan post test mengalami penurunan 1 responden dengan prosentase $14 \%$.

Hasil uji statistik Wilcoxon sign rank menunjukkan kelompok eksperimen A sebesar 0,000, kelompok eksperimen B memiliki nilai sebesar 0,000 yang menunjukkan nilai $\mathrm{p}<\alpha(\alpha=0,05)$, maka keputusan yang diambil adalah Ho ditolak atau hipotesis penelitian diterima, artinya terdapat perbedaan pengetahuan yang lebih baik saat setelah dilakukan intervensi menggunakan buku saku PHBS di sekolah. Pada kelompok kontrol, memiliki nilai Asymp. Sig. (1-tailed) sebesar 0,275 yang menunjukkan nilai $p>\alpha(\alpha=0,05)$, maka keputusan yang diambil sebaliknya, tidak adanya perbedaan pengetahuan pada kelompok kontrol ini karena tidak dilakukannya intervensi apapun.

Efektivitas media promosi kesehatan buku saku PHBS di sekolah dalam meningkatkan pengetahuan, sikap dan intensi dapat dilihat pada tabel 3 .

Tabel 3. Efektivitas Media Buku Saku PHBS di Sekolah dalam Meningkatkan Pengetahuan, Sikap, dan Intensi

\begin{tabular}{cccc}
\hline Kelompok & \multicolumn{3}{c}{ Mean Rank } \\
\cline { 2 - 4 } & Pengetahuan & Sikap & Intensi \\
\hline $\begin{array}{c}\text { Eksperimen } \\
\text { A }\end{array}$ & 60,39 & 56,34 & 58,16 \\
$\begin{array}{c}\text { Eksperimen } \\
\text { B } \\
\text { Kontrol }\end{array}$ & 43,62 & 46,29 & 48,16 \\
& 27,07 & 28,31 & 24,69 \\
\hline
\end{tabular}


Berdasarkan tabel 5 hasil uji statistik nilai pengetahuan pada tiga kelompok ini menggunakan Uji Kruskal Wallis dengan SPSS 20. Kelompok eksperimen A yang diberikan buku saku PHBS di sekolah dan penyuluhan, memiliki nilai mean rank 60,39. Kelompok eksperimen B yang diberikan buku saku PHBS di sekolah memiliki nilai mean rank 43,62, dan kelompok kontrol memiliki nilai mean rank 27,07. Hal ini menunjukkan bahwa perlakuan kelompok eksperimen A lebih efektif dari pada perlakuan kelompok eksperimen $\mathrm{B}$, dan kelompok eksperimen B lebih efektif daripada kelompok kontrol.

Hasil uji statistik nilai sikap pada kelompok eksperimen A memiliki nilai mean rank 56,34. Kelompok eksperimen B 46,29, dan kelompok kontrol 28,31, sedangkan hasil uji statistik nilai intensi pada pada kelompok eksperimen A memiliki nilai mean rank 58,16, kelompok eksperimen B memiliki nilai mean rank 46,16, dan kelompok kontrol memiliki nilai mean rank 24,69. Hal ini menunjukkan bahwa perlakuan kelompok eksperimen A lebih efektif dari pada perlakuan kelompok eksperimen $\mathrm{B}$, dan kelompok eksperimen B lebih efektif daripada kelompok kontrol dalam meningkatkan sikap dan intensi responden.

Jenis kelamin responden merupakan pengelompokan responden yang dibedakan antara laki-laki dan perempuan. Hasil penelitian menunjukkan bahwa sebaran responden berdasarkan jenis kelamin yang paling banyak adalah pada perempuan. Tingkat Pendidikan responden merupakan pengelompokkan responden berdasarkan tingkat kelas. Determinan perilaku menjelaskan bahwa determinan internal yang termasuk dalam perilaku yaitu karakteristik seseorang yang bersifat given atau bawaan seperti kecerdasan, emosi, tingkat pendidikan, dan jenis kelamin. Kesimpulan yang didapat adalah faktor jenis kelamin dan pendidikan merupakan karakteristik yang bersifat bawaan yang dapat mempengaruhi respon setiap individu terhadap sebuah rangsangan atau stimulus (Gani, H.A., Istiaji, E., Kusuma, A.I, 2014).

Penambahan intervensi dengan penyuluhan merupakan sarana edukatif untuk meningkatkan pengetahuan seseorang. Tujuan akhir penyuluhan adalah adanya perubahan perilaku manusia yang dilakukan secara edukatif (Nuryanto, Pramono, Puruhita, N., Muis,S., 2014). Hasil analisis menunjukkan bahwa terdapat perbedaan signifikan pada kelompok eksperimen A dan B, mayoritas responden mengalami peningkatan pengetahuan antara pretest dan post test, artinya terdapat perbedaan pengetahuan yang lebih baik saat setelah dilakukan intervensi. Pada kelompok kontrol tidak terdapat perbedaan yang signifikan, artinya tidak adanya perbedaan pengetahuan pada kelompok kontrol ini karena tidak dilakukannya intervensi apapun.

Berdasarkan uji diatas dapat diketahui bahwa terdapat perbedaan tingkat pengetahuan sebelum dan sesudah pemberian intervensi. Penelitian laindengan judul hubungan tingkat pengetahuan dengan perilaku anak sekolah tentang hidup bersih dan sehat di Sekolah Dasar Negeri wilayah Puskesmas Selemadeg Timur II menjelaskan bahwa semakin tinggi tingkat pengetahuan siswa semakin baik tingkat perilakunya. Hal ini menunjukkan adanya hubungan tingkat pengetahuan dengan perilaku anak sekolah dasar negeri wilayah Puskesmas Selemadeg Timur II (Sulastri, K., Nyoman, I., Gede., 2014).

Hasil analisis menunjukkan bahwa terdapat perbedaan sikap signifikan pada kelompok eksperimen A dan B, mayoritas responden mengalami peningkatan sikap antara pre test dan post test, artinya terdapat perbedaan sikap yang lebih baik saat setelah dilakukan intervensi menggunakan buku saku PHBS di sekolah. Pada kelompok kontrol diketahui tidak ada perbedaan signifikan.

$$
\text { Nilai post test sikap pada }
$$

kelompok kontrol diketahui mengalami penurunan 1 responden dari kategori baik, hal ini sesuai dengan penelitian sebelumnya oleh Saloso tentang pengaruh media audio (lagu anak- anak) dan media visual (kartu bergambar) terhadap pengetahuan gizi (PUGS dan PHBS) serta tingkat penerimaannya pada anak usia sekolah dasar negeri di Kota Bogor yang menyatakan bahwa penurunan jumlah pertanyaan yang tidak mampu dijawab oleh sebagian besar kelompok kontrol saat postest disebabkan 
oleh pendidikan gizi dan PHBS yang tidak didapatkan kelompok kontrol (Saloso, 2011). Penelitian yang dilakukan oleh Nuryanto et al. yang menjelaskan bahwa peningkatan sikap anak disebabkan oleh meningkatnya pengetahuan anak. Peningkatan pengetahuan akan membantu sikap anak dan mempengaruhi kebiasaan anak (Nuryanto, Pramono, Puruhita, N., Muis, S., 2014).

Hasil analisis menunjukkan bahwa terdapat perbedaa $\mathrm{n}$ sikap signifikan pada kelompok eksperimen A dan B, mayoritas responden mengalami peningkatan intensi antara pre test dan post test, artinya terdapat perbedaan sikap yang lebih baik saat setelah dilakukan intervensi. Pada kelompok control diketahui tidak ada perbedaan signifikan.

Penelitian yang dilakukan oleh Gusti menjelaskan bahwa perubahan perilaku seseorang dapat dipengaruhi oleh pengetahuan, sikap dan intensi. Hasil penelitian menunjukkan adanya hubungan antara pengetahuan dengan sikap terhadap pengelolaan sampah berkelanjutan; ada hubungan antara pengetahuan tentang pengelolaan sampah berkelanjutan dengan intensi perilaku pengelolaan sampah berkelanjutan; dan ada hubungan antara sikap terhadap pengelolaan sampah berkelanjutan dengan intensi perilaku pengelolaan sampah berkelanjutan pada siswa sekolah dasar (Gusti, Isyandi, Bahri, Afandi., 2015).

Pengukuran efektivitas media buku saku PHBS di sekolah ini berdasarkan hasil mean rank dari 3 kelompok, dengan hasil pada kelompok eksperimen A lebih efektif dari pada perlakuan kelompok eksperimen B, dan kelompok eksperimen B lebih efektif daripada kelompok kontrol. Hal ini menunjukkan bahwa media cetak yaitu buku saku PHBS di sekolah efektif dalam meningkatkan pengetahuan, sikap dan intensi PHBS.

Proses difusi inovasi telah terjadi di dalam penelitian kelompok eksperimen A dan kelompok eksperimen $\mathrm{B}$, responden mampu menerima inovasi yang ada dan buku saku PHBS di sekolah efektif dalam menigkatkan pengetahuan, sikap dan intensi dalam berPHBS. Terdapat 3 tahapan difusi inovasi yang telah dilalui, yaitu pengetahuan, persuasi, dan keputusan. Pada tahap pengetahuan, sasaran telah di berikan informasi mengenai 8 indikator PHBS baik melalui buku saku PHBS di sekolah maupun dari penyuluhan, kemudian pada tahap persuasi terlihat mulai adanya ketertarikan responden terhadap buku saku PHBS di sekolah sebagai pegangan dalam berPHBS. Pada tahap keputusan terdapat peningkatan nilai pengetahuan, sikap dan niat responden yang menyatakan menerima inovasi berupa media cetak tersebut.

Media promosi sebagai alat untuk promosi kesehatan yang kuat dengan jangkauan yang luas. Manfaat dari intervensi menggunakan media promosi dapat mempertahankan niat dan meningkatkan perhatian responden terhadap intervensi yang diberikan.Penelitian lain yang mendukung terkait efektifitas media promosi kesehatan tentang PHBS yaitu berupa video animasi cuci tangan pakai sabun sebagai salah satu alternatif penerapan PHBS untuk anak tunadaksa, media tersebut terbukti efektif (Mangarapian, 2017). Penelitian yang dilakukan oleh Bayu menjelaskan bahwa adanya efektivitas dari media promosi kesehatan berupa media cetak, dalam penelitian ini menggunakan media cetak brosur dan leaflet pada pasien hipertensi, hasilnya informan memutuskan untuk menerima/megadopsi media promosi kesehatan dengan cara melaksanakan anjuran pada media cetak tersebut tanpa adanya paksaan melainkan informan sadar akan pentingnya kesehatan (Bayu, 2017). Media "Piring Makanku" produk Kementerian Kesehatan RI terbukti efektif dalam meningkatkan pengetahuan, sikap dan praktik gizi seimbang dalam sekali makan, karena terdapat perbedaan yang signifikan nilai lebih baik diantara kelompok perlakuan dan kelompok kontrol dalam hasil nilai post test pengetahuan, sikap, dan praktik (Pratama, A.P., Zulkarnain, E., Ririanty, M., 2017). Penelitian tentang buku saku yang dilakukan oleh Eliana dan Solikhah, menyatakan bahwa adanya efektivitas dari buku saku gizi berdasarkan perbedaan tingkat pengetahuan gizi antara sebelum (pre test) dan sesudah (post test) diberikan buku saku gizi dengan nilai mean sebelum diberikan buku saku 71,33 dan mean sesudah diberikan buku saku 91,07 artinya ada pengaruh Buku 
Saku Gizi terhadap tingkat pengetahuan gizi pada anak kelas 5 Sekolah Dasar Muhammadiyah Dadapan Desa Wonokerto Kecamatan Turi Kabupaten Sleman Yogyakarta (Solikhah, 2012).

\section{Simpulan dan Saran}

\subsection{Simpulan}

a. Karakteristik responden dalam penelitian ini yaitu pendidikan responden mulai kelas 4 sampai 6 dan jenis kelamin responden sebagian besar berjenis kelain perempuan;

b. Nilai pengetahuan lebih baik saat setelah diberikannya intervensi pada kelompok eksperimen A dan B;

c. Nilai sikap lebih baik saat setelah diberikannya intervensi pada kelompok eksperimen A dan B;

d. Nilai intensi lebih baik saat setelah diberikannya intervensi pada kelompok eksperimen;

e. Media buku saku PHBS di sekolah dan penyuluhan efektif dalam meningkatkan pengetahuan, sikap dan intensi pada kelompok eksperimen A, namun buku saku PHBS di sekolah saja juga efektif pada kelompok eksperimen B daripada kelompok kontrol yang tidak diberikan perlakuan apapun.

\subsection{Saran}

Perlu adanya penelitian selanjutnya untuk menguji keefektifan buku saku PHBS di sekolah menggunakan variabel praktik dalam berPHBS. Penelitian lanjutan dapat pula dilakukan dengan variabel yang sama yaitu pengetahuan, sikap dan intensi kepada populasi yang lebih luas dan merata, dikarenakan penelitian ini hanya tertuju kepada satu wilayah saja.

\section{Daftar Pustaka}

Bayu, D. (2017). Efektivitas Media Promosi Kesehatan Leaflet dan Brosur pada

Pasien Hipertensi. Digital Repository

Universitas Jember. Available : $24 \quad$ Desember 2017 http://repository.unej.ac.id/handle/123 $456789 / 8128$
Dinas Kesehatan Kota Surabaya. (2016). Laporan PHBS kota Surabaya. Surabaya: Dinas

Kesehatan Kota Surabaya

Gani, H.A., Istiaji, E., Kusuma, A.I. (2014). Perbedaan Efektivitas Leaflet dan Poster Produk Komisi Penanggulangan AIDS Kabupaten Jember dalam Perilaku Pencegahan HIV/AIDS. Jurnal IKESMA Universitas Jember, 10.

Glanz, Karen., Barbara K. Rimer., K. Viswanath. (2008). Health Behavior And Health Education. San Fransisco: Jossey Bass.

Gusti, Isyandi, Bahri, Afandi. (2015). Hubungan Pengetahuan, Sikap dan Intensi Perilaku Pengelolaan Sampah Berkelanjutan Pada Siswa Sekolah Dasar di Kota Padang. Jurnal Dinamika Lingkungan Indonesia, 2 (2). Available : 09 Oktober 2017.

Kholid, A. (2014). Promosi Kesehatan: D'engan Pendekatan Teori Perilaku, Media, dan Aplikasi untuk Mahasiswa dan Praktisi Kesehatan. Jakarta: Rajawali Pers.

Mangarapian, B.M.P., (2017). Penilaian Efektifitas Media Promosi Kesehatan Berupa Video Animasi Cuci Tangan Pakai Sabun sebagai Salah Satu Alternatif Penerapan Perilaku Hidup Bersih dan Sehat (PHBS) Untuk Anak Tunadaksa. Digital Repository Universitas Jember. Available : 25 Juni 2018 http://repository.unej.ac.id/bitstream/h andle/123456789/80929/Brahma

Luthviatin, N., Zulkarnain, E., Istiaji, E., Rokhmah., D. (2012). Dasar-Dasar Promosi Kesehatan \& Ilmu Perilaku. Jember: UPT Penerbitan UNEJ.

Nuryanto,Pramono, Puruhita, N., Muis, S. (2014). Pengaruh Pendidikan Gizi terhadap Pengetahuan dan Sikap 
ISSN 2354-5852

E-ISSN 2579-5783

tentang Gizi Anak Sekolah Dasar. Jurnal Gizi Indonesia Universitas Diponegoro.

Notoatmodjo, S. (2012). Metodologi Penelitian Kesehatan. Jakarta: Rineka Cipta

Pratama, A.P., Zulkarnain, E., Ririanty, M. (2017). Efektivitas Media Promosi "Piring Makanku" Pedoman Gizi Seimbang Sebagai Panduan Sekali Makan. Jurnal Pustaka Kesehatan, .6 (1), 53-59.

Puskesmas Krembangan Selatan. (2017). Data Kunjungan Puskesmas. Surabaya

Saloso, I. (2011). Pengaruh Media Audio (Lagu Anak-anak) dan Media Visual (Kartu Bergambar) terhadap Pengetahuan Gizi (PUGS dan PHBS) serta Tingkat Penerimaannya pada Anak Usia Sekolah Dasar Negeri di Kota Bogor. Skripsi. Bogor: Institut Pertanian Bogor.

Solikhah, Eliana. (2012). Pengaruh Buku Saku Gizi Terhadap Tingkat Pengetahuan Gizi Pada Anak Kelas 5

Muhammadiyah Dadapan Desa

Wonokerto Kecamatan Turi Kabupaten Sleman Yogyakarta. Jurnal KESMAS $U A D, 6$ (2).

Sulastri, K., Nyoman, I., Gede. (2014). Hubungan Tingkat Pengetahuan dengan Perilaku Anak Sekolah tentang Hidup Bersih dan Sehat di Sekolah Dasar Negeri Wilayah Puskesmas Selemadeg Timur II. Jurnal Kesehatan Lingkungan Poltekkes Denpasar,4 (1).

Susanto, Tantut, Lantin, Emi, Syahroni. (2016). A cross-sectional study on Clean and Healthy Living Program Behavior (CHLB) among Islamic Boarding Schools in Indonesia.
International Journal of Nursing Sciences, 3, 291-298. 
ISSN 2354-5852

E-ISSN 2579-5783

53 | Jurnal Kesehatan Vol. 6. No. 2. Agustus 2018 